\title{
Knowledge, Attitude, and Prevention Practice on Dengue and Dengue Seroprevalence in a Dengue Hotspot in Sabah, East Malaysia
}

\section{Rhanye Mac Guad ( $\sim$ hanye@ums.edu.my )}

Universiti Malaysia Sabah School of Medicine: Universiti Malaysia Faculty of Medicine and Health Sciences https://orcid.org/0000-0003-2453-3760

\section{Maw Shin Sim}

Universiti Malaya Fakulti Perubatan: University of Malaya Faculty of Medicine

\section{Yuan Seng Wu}

Sunway University

Yin Nwe Aung

UCSI: UCSI University

Wah Yun Low

Universiti Malaya Fakulti Perubatan: University of Malaya Faculty of Medicine

\section{Shamala Devi Sekaran}

UCSI: UCSI University

Nornazirah Azizan

Universiti Malaysia Sabah School of Medicine: Universiti Malaysia Faculty of Medicine and Health Sciences

\section{Research}

Keywords: Dengue infection, KAP, seroprevalence, migrant, tropical country, Sabah Malaysia

Posted Date: November 17th, 2021

DOI: https://doi.org/10.21203/rs.3.rs-1066975/v1

License: @ (i) This work is licensed under a Creative Commons Attribution 4.0 International License. Read Full License 


\section{Abstract}

Background: Dengue, a major global public health concern, is growing more prevalent. Extensive measures have been undertaken to prevent and control dengue transmission in Malaysia including understanding and modification of human behaviour. This study was designed to assist in planning an effective health intervention for dengue by measuring residents' knowledge, attitudes, and practice (KAP) in hotspot areas of Sabah, East Malaysia. Methods: A community-based and cross-sectional study was conducted at dengue hotspot area in Sabah involving 463 residents (aged 18 years and above). Information on the socio-demographic characteristics of the residents and their KAP towards dengue was collected using a structured pre-validated questionnaire developed by the researchers. In addition, residents were invited to participate in a dengue seroprevalence study using dengue Immunoglobulin $\mathrm{M}$ (IgM) and Immunoglobulin G ( $\mathrm{lgG}$ ) ELISA kit. Results: Most of the residents correctly identified common signs and symptoms of dengue such as fever (84.4\%), chills (70.7\%), and nausea or vomiting (56.0\%). Nearly half of the residents $(51.3 \%)$ had good knowledge, $66.0 \%$ had a positive attitude, and $63.7 \%$ had a positive practice for dengue prevention and control, respectively. The dengue seroprevalence study included 200 of the 463 residents; IgG and IgM seropositivity was $74.1 \%$ $(n=63)$ and $7.1 \%(n=6)$ respectively. Based on logistic regression analysis, local and migrants differs considerably in terms of their knowledge and attitude toward dengue prevention and control, while gender and level of education were predictive of practice level $(p<0.05)$ among all sociodemographic variables examined. Knowledge was correlated with attitude $(p<0.0001)$ and practice $(p<0.0014)$. Discussion: To combat dengue epidemics in the hotspot area of Sabah, a proactive and behavioural changes among residents, are required. To effectively prevent and manage dengue transmission, a collaborative effort of government sectors, private sectors, housing residential committees, and community residents is essential.

\section{Background}

In Malaysia, the annual accumulative dengue incidence continues to rise year on year; in 2018 , there were 80,615 cases reported, which grew to 130,101 in 2019 (a 61.4\% increase), indicating that the country's dengue incidence rate is currently at 390.4 per 100,000 people (1). Dengue is more common in areas undergoing rapid urbanization such as the Federal Territory of Kuala Lumpur, the state of Selangor, and the state of Johor in Malaysia $(2,3)$. Interestingly, the state of Sabah in East Malaysia has consistently been ranked highly in the country for dengue cases (1). The annual dengue incidence rates in Sabah were spatially variable over the period of 2010-2016, with average annual incidence of 21 cases per 100,000 people (1). According to a recent study by Murphy, A et al (2020), dengue cases in Sabah primarily affected rural areas in the Western districts (Kuala Penyu, Nabawan, Tenom, and Kota Marudu), with a smaller number of more severe cases in the eastern districts (Sandakan and Tawau) (4).

According to the latest national statistics, as of mid-2015 Sabah has a population of approximately 3.7 million (5), making it the third most populous state in Malaysia. It is home to diverse ethnicities comprising mainly of indigenous communities of Kadazandusun (25\%), Bajau (15\%) and Murut (3\%) (6). Over the years, Sabah has also experience increasing number of migrants, accounting for $27.7 \%(886,400)$ of Sabah population $(7)$, with most migrants being of Indonesian (85\%) and Filipino (15\%) origin (8). Several reasons led to increase migrants in Sabah such as religions, political and economics advantageous (9). As a result of increasing population density, urbanization have extended outwards from towns and cities to the outskirts, resulting in enormous social and economic changes. For example, in the town of Telipok (urban expanse of Kota Kinabalu, the capital city of Sabah), urbanisation has resulted in the growth of low-cost homeownership, due to high demand from the low-income group. Water supply services are frequently disrupted in this town, which has an admixed population of both locals and migrants, as are irregular sewage systems for draining rainwater and inefficient garbage collection services. Unsurprisingly, these interconnected

Page $2 / 20$ 
components linked to human migration, environmental changes, and urbanisation have facilitated the spread of dengue (10) across Sabah.

The fact that there are no effective antiviral medications available for dengue further complicates the situation. As a result, holistic prevention - which includes the eradication of breeding sites, environmental management, and good community engagement and cooperation, is the most effective method for dengue prevention and control. According to a study, sociodemographic variables, behaviour, and belief in the community are all closely linked to dengue prevention and control (11). Despite the fact that the health authorities in Sabah launched massive health outreach campaigns, the communities' attitudes and practices remained unchanged, as evidenced by high dengue infection rates. As a result, the current study measured community residents' KAP in hotspot areas of Sabah, East Malaysia, in order to gain a better understanding of population health and to stimulate public health formulations to develop an effective dengue health intervention.

\section{Methods}

\section{Study design and setting}

A community-based and cross-sectional study was conducted at Taman Telipok Ria and Taman Sri Rugading, which are two residential areas located at Telipok district, a hotspot dengue cases in Sabah (12). The residential apartments consist of five-story walk-up apartment complexes with both low- and high-density units. The study utilized convenience sampling to collect data from residents' homes as well as a community clinic in the proximity of the housing area (Fig 1).

\section{Definition of terms}

Being of Malaysian nationality is based on Malaysia's citizenship constitution, which states that that someone is a Malaysian national if either one of his or her parents is a Malaysian or a permanent resident at the time of birth, or he or she was born in Malaysia and is not a citizen of any other country (13). Two staff nurses were assigned to properly check the residents' citizenship by questioning them about their family background. A dengue hotspot is defined as an area where a dengue outbreak has been prevalent for more than 30 days (12).

\section{Participation and sample size}

Data was collected from April 2020 through February 2021, following written approval from the housing management bodies and district police offices. Residents who were aged at least 18 years and above and those provided informed consent were solicited to participate in the study. Residents self-administered the questionnaire and were doublechecked to ensure that they had answered all of the questions. Based on G*Power3.1 software, with effect size $=0.3, a$ error probability $=0.05$ and power $(1-\beta$ error probability $)=0.95$, a total of 134 residents were required to achieve the minimum recommended sample size (14).

\section{KAP survey questionnaire}

Information on the socio-demographic characteristics of the residents and their KAP towards dengue was collected using a structured questionnaire developed by the researchers. Prior to the actual data collection, a pilot study and exploratory factor analysis (EFA) study involving 30 and 468 residents respectively was conducted to validate the questionnaire written in native Sabah creole (15). There are three sections to the questionnaire. Section A consists of nine questions designed to test residents' general knowledge of dengue, including dengue transmission, vector biology, clinical symptoms, names of major dengue vectors, breeding habitats, active time of dengue vectors, and treatments 
for dengue (if any). Section B comprises eight items relating to residents' attitude towards dengue, such as importance of maintaining a clean and vector breeding free environment, vector control, and the role of community residents on vector control. Lastly, Section $\mathrm{C}$ consisted of 11 items relating to the residents' usual dengue prevention practices such as maintaining a clean environment, home gardening practices, covering of water storage tanks, and use of Abate ${ }^{\circledR}$, a larvicide, as vector control. The survey questionnaire is attached supplementary file.

\section{Dengue seroprevalence test}

In addition to the KAP survey, residents were invited to participate in a dengue seroprevalence study. Three millilitres of venous blood were collected in ethylenediaminetetraacetic acid (EDTA) blood tubes, maintained at room temperature, and delivered to the laboratory in four hours. The blood was then centrifuged for 4 minutes at 4,000 rpm, and the serum was aliquoted, coded, and kept at $-80^{\circ} \mathrm{C}$ for later use. According to the manufacturer's instructions, a dengue IgM and IgG ELISA kit (Standard Diagnostics Inc., Yongin-si, Gyeonggi-do, Republic of Korea) was used to determine the presence of anti-dengue immunoglobulins in the sera. The presence of anti-dengue immunoglobulins in the serum of each community resident was conducted in duplicate. Dengue IgM positivity indicates an acute dengue infection, whereas dengue IgG positivity indicates past dengue exposure (16).

\section{Data management and statistical analysis}

Both the KAP questionnaire and blood sample of the residents were coded with a unique identification number based on their residential address. Data analysis was performed using Statistical Package for Social Science version 23 (SPSS, Inc., Chicago, IL). A scoring system was utilised to evaluate KAP data. All correct and positive responses in the knowledge and practice sections received a score of one, while "don't know" and incorrect responses received a score of zero. The attitude section is scored on a Likert scale, with one being the lowest and five being the highest. Strongly agree to positive statements and strongly disagree to negative statements obtained a score of five, while strongly disagree to positive statements and strongly agree to negative comments received a score of one. The KAP level was calculated based on the total number of correct answers in each section. A resident would be labelled as "good" if he or she scored at least $80 \%$ in a category; if the score was less than $80 \%$, the resident would be labelled as "poor." The KAP survey's scoring system and cut-off points were based on earlier research $(17,18,19)$. Frequencies and percentages were used in the sociodemographic factors' descriptive statistics. The chi-square test or Fisher's exact test were used to examine the relationship between the independent variable and the KAP level (good or poor). The relationship between good KAP and demographic and socioeconomic characteristics was investigated using univariate logistic regression analysis. The statistical significance level was set to 0.05 . On the other hand, Spearmen's rank correlation was employed to establish the extent of correlation between KAP scores.

\section{Results}

\section{Social and demographic characteristics of study population}

A total of 463 neighbourhood residents agreed to participate out of 480 who were approached, giving a response rate of $96.6 \%$. The sociodemographic characteristics of the residents are shown in Table 1. The mean age was $31 \pm 9.467$ years. Females made up the majority of the study population (88.1\%), which could be explained by the fact that they were recruited at a community clinic within the vicinity of an apartment that caters mostly to pregnant women's followup.

Although both locals and migrants occupy the apartments, the majority are migrants as many of the apartment units are rented out to migrants. In terms of race, the majority were Bajau (37.6\%), followed by Bugis (15.3\%) and Suluk 
(13.3\%). More than three-quarters of those surveyed had completed at least high school (74.1\%). Only $28.1 \%$ of the total residents were employed, and 69.3\% earned more than RM1,000 each month.

The findings showed that $92.9 \%$ of residents had no prior dengue infection. Among 463 residents, only 200 residents participated in the dengue seroprevalence study, out of which $74.1 \%(n=63)$ and $7.1 \%(n=6)$ tested seropositive for dengue $\lg \mathrm{G}$ and $\lg \mathrm{M}$, respectively.

\section{Knowledge about dengue prevention and control}

Table 2 highlights the residents' dengue knowledge, indicating a high degree of knowledge on dengue disease and transmission. Of the $86.8 \%$ of residents who answered the knowledge section, more than half correctly answered the statements $(51.3 \% \pm 14.4)$. For example, more than half of the residents correctly identified fever $(84.4 \%)$, chills $(70.7 \%)$, and nausea or vomiting (56.0\%) as signs and symptoms of dengue. Despite this, several residents misidentified coughing (19.3\%) and swollen lymph nodes (13.9\%) as signs and symptoms of dengue. Although only $30.5 \%$ of residents were aware that dengue is an infectious disease, the majority of the residents (94.7\%) were aware that it is spread by mosquito bites, specifically Aedes species (79.9\%). Furthermore, the majority of residents were able to accurately answer questions about vector behaviour, namely vectors' active biting times (62.5\%) and breeding preferences, such as discarded food containers (64.0\%), open pools of water (94.8\%), and exposed water reservoirs (69.9\%). However, knowledge of the fact that there is no specific treatment for dengue was lacking, with over half of the residents $(60.8 \%)$ believing that there is. Despite this, the majority of residents were aware of the necessity to rest (57.6\%) and drink abundant water (76.3\%) for dengue recovery. Surprisingly, residents were aware of the potential of fines if mosquito larvae were discovered in residential property $(87.5 \%)$.

\section{Attitudes of the residents toward dengue prevention and control}

The attitude of residents towards dengue prevention is presented in Table 3. On average, the attitude score was $66.0 \%$ $\pm 9.0(n=427)$. More than two third of residents $(76.5 \%)$ agreed that dengue is an illness that can be prevented.

Furthermore, $93.0 \%$ of them agreed that mosquito larvae must be disposed of to avoid dengue spread. Less than half of the residents (45.0\%) believed that killing a dengue-carrying mosquito was the only approach to control or prevent infection with $52.7 \%$ of the residents believed that "fogging" could fully prevent mosquito breeding. Furthermore, $32.2 \%$ of residents said that at least once a year, frequent supervision to control and monitor probable mosquito breeding sites should be conducted, and $57.6 \%$ of the residents agreed that fines may help with dengue control. Although the majority of respondents (91.2\%) agreed that routine inspections of residential premises should be conducted, a large number of residents responded that health professionals and volunteers were not the only ones responsible for reducing mosquito breeding grounds $(75.3 \%)$.

\section{Practices of the residents toward dengue prevention and control}

In terms of dengue prevention practices by the residents, the results are summarised in Table 4 . The study showed that the average preventive practice score was $63.7 \% \pm 21.1(n=435)$.According to the findings, more than half of the residents (69.9\%) utilised lids for any water containers at home and closed them after each usage or checked their stored water in containers on a frequent basis (71.4\%). Abate ${ }^{\circledR}$, a larvicide that prevents vector-borne disease including dengue, was used by $28.7 \%$ of the residents, who were either given it by health inspectors or bought it themselves. More than a third (42.4\%) of those who used flower vases checked for mosquito larvae on a regular basis and dumped stagnant water in the vase (49.9\%) to avoid mosquito breeding. Furthermore, majority of residents had a habit of inspecting their home and property for a container or location that could provide a breeding ground for mosquitoes $(81.7 \%)$ or removing containers that could contribute to water accumulation and stagnation (93.8\%). Lastly, the 
majority of residents (97.5\%) agreed that eliminating Aedes mosquitoes is a shared responsibility and that they are prepared to work with local authorities to execute dengue prevention measures at their residence (97.7\%).

\section{Factors associated with good dengue KAP}

Next, association analysis was performed between different factors and good KAP as shown in Table 5. Nationality was shown to be significantly associated with good knowledge; local Sabahan residents had considerably higher knowledge on dengue than migrants' residents [8.673 (1.774-42.383), $p=0.0026$ ]. There was no association between level of knowledge and residents' age, gender, marital status, level of education, occupation, monthly income, or previous experience of dengue. In terms of attitudes toward dengue prevention and control, local Sabahan residents showed a three-fold better attitude than migrants [3.333 (1.529-7.267), $p=0.0024]$. Furthermore, residents with at least a secondary school education showed two times better attitudes toward dengue prevention than those without [2.379 (0.880-10.062), $p=0.009]$. Finally, the study found that community residents' gender [2.651 (1.257-5.590), $p=0.0054]$ and degree of education [2.976 (1.391-4.071), $p=0.0461]$ were both significantly associated with good dengue prevention practices.

Table 6 shows the level of association between knowledge-attitude, knowledge-practice, and attitude-practice. Knowledge-attitude $\left(r_{s}=0.2768, p=0.0001\right)$ and knowledge-practice $\left(r_{s}=0.1614, p=0.0014\right)$ had a strong positive correlation. However, no correlation between attitude and practise was demonstrated $\left(r_{s}=-0.0039, p=0.9374\right)$. On average, it was demonstrated that the degree of correlation between KAP domains was fair $\left(r_{s}<0.5\right)$.

\section{Discussion}

This is the first study to describe dengue KAP in a mixed population of locals and migrants in Sabah, Malaysia, that has consistently contributed to high dengue cases. To the best of our knowledge, no research has been done in Malaysia to investigate the link between dengue KAP and migrants. Overall, more than half of the residents were found to have adequate knowledge of dengue, an acceptable attitude toward dengue prevention, and a satisfactory practice of dengue prevention. Furthermore, this study reveals that knowledge and attitude are associated with nationality independently; however, among resident in the community dengue prevention practices are more related to gender and level of education. Both attitudes and practices are substantially correlated with community residents' knowledge of dengue.

KAP has been assessed in a variety of research studies in Malaysia, but only two studies have examined KAP relating to dengue in both hotspot and non-hotspot areas - finding that knowledge is influenced differently by race, marital status, monthly income, employment $(18)$ and educational level $(18,20)$. On average, the percentage score for KAP was higher than previous studies in hotspot areas in Malaysia (18) (51.3\% versus $50.7 \%, 66.0 \%$ versus $53.2 \%$ and $63.7 \%$ versus $50.2 \%$, respectively). This disparity could be explained by a variety of factors, including a person's lack of exposure to a dengue awareness campaign (18), or in the case of this study, reluctance to cooperate due to fact that most of the residents are migrants (70.4\%): they might feel additional pressure, a loss of a sense of community, disinterest, or concern as some of them do not possess valid documents to stay in Sabah. It is worth noting that unreliable or improper data collection methodologies or questionnaire use could also contribute to the differences in findings of a study (21). It has been demonstrated that measurement properties are population-specific and vary based on the questionnaire's setting and context (22). A questionnaire designed for one demographic may not be appropriate to another in a different country or region with differing socio-cultural, healthcare, economic, and political circumstances, resulting in discrepancies in the findings. Prior to the actual data collection, a pilot study and EFA were 
conducted, and the resulting KAP items were kept in the final version of the survey questionnaires, indicating a reliable and valid questionnaire for the Sabah population (15).

As this study included $88.1 \%$ females, the majority of whom were pregnant (86.2\%), it will provide insight into the level of knowledge on dengue among pregnant women in Sabah. Several reviews of case reports have found that dengue infection before and even during pregnancy can result in negative effects for the foetus due to vertical antibody transmission (23). This is worrying as $74.1 \%$ of the 85 pregnant women who participated in the study's seroprevalence testing had previously been unwittingly exposed to dengue. When these two factors are combined, pregnant women may inadvertently become infected with dengue, putting this susceptible group, as well as the foetus, at risk of complications during pregnancy as a result of unnoticed dengue. A previous study in Malaysia (24) found a prevalence rate of $2.5-3.4 \%$ of acute dengue infection among pregnant women. These studies have demonstrated the necessity of health counselling on dengue infection during clinic visits among these pregnant women.

Nationality was consistently related with better knowledge of dengue in both univariate and multivariate analyses. Migrants of Bajau, Bugis, Suluk, Jawa, and Bisaya ethnic backgrounds who came from Indonesia or the Philippines, had less knowledge than local Sabahan. A study among Myanmar migrant women caretakers in Mae Sot District, Tak Province, Thailand (25) showed that they had comparable knowledge of active biting from the mosquitoes carrying dengue virus during the day (56.7\% versus $61.6 \%)$, common dengue symptoms $(71.0 \%$ versus $69.7 \%)$, and discarded bottles and old tires that could potentially breed Aedes mosquitoes (75.0\% versus 61.5\%). Early reports (26) suggest that increased length of stay in a country and availability of dengue information in the local language (27) may lead to greater dengue knowledge among migrants. This highlights the urgent need for effective steps to eliminate obstacles to acquiring dengue information for migrants, such as increasing healthcare provider training regarding migrants and implementing health literacy education programmes focusing on migrants.

Community residents residing at these hotspot areas have some noteworthy flaws in understanding as observed in the context of our study. For example, more than a third of residents had the misconception that dengue is an illness that cannot be prevented. This misconception must be dispelled since people will not engage in healthy behaviour unless they value the behaviour's outcome (28). Out of 444 residents, slightly more than half $(50.2 \%)$ had the erroneous belief that chemical fogging by the health personnel is adequate to reduce dengue transmission, which is comparable to the results reported by Kamel et al. (2017) (29) and Selvarajoo, S et al (2020) (18) (47\% and 49.6\%, respectively). Paradoxically, fogging is always carried out after cases are reported in Malaysia, and studies have indicated that chemical fogging does not prevent the breeding of mosquitoes completely (12). According to the logistic analysis, residents with a higher level of education had a positive attitude toward dengue prevention, which is consistent with findings from previous studies in Malaysia (30) and Colombia (31). This could be because people with a higher level of education are more involved in the community: they are more likely to lead meetings, educate other family members and/or neighbours, and more frequently believe they have the ability to take control of their actions, with their suggestions accepted and a sense of responsibility. This shows that a person's level of education may be connected to their ability to integrate and coordinate efforts to limit dengue transmission. However, education alone does not have a significant impact on attitudes. This could be due to societal differences, such as those found in this mixed-nationality community, which prohibit the populace from participating in the national strategy for dengue prevention and control.

The current study also reveals some intriguing findings on community residents' dengue-related activities. Although the majority of residents agreed that eradicating Aedes mosquitoes is a shared responsibility and stated their willingness to work with local health authorities to conduct dengue-preventive initiatives at their homes, surprisingly, a third of these residents stated that health inspectors aren't required to inspect residential properties. This phenomenon may be explained by the fact that this residential area is primarily occupied by migrants who are frightened of being 
discovered working without a permit by government officials. Another possible explanation is that these migrants usually originated from conflict-affected areas, had deprived sociodemographic and poor educational backgrounds, and strong beliefs in traditional health. These factors could act as a barrier to health communication, as low health literacy has been associated with adverse health outcomes across many domains and contexts (32). An interesting approach suggested by Gilder, M.E et al (2019) (33) dealing with migrant's worker communities on the MyanmarThailand border showed the importance of public health posters that need piloting prior to implementation due to the fact that unanticipated misperceptions are common among migrants. The study further emphasized that verbal communication remains a key method of sharing messages with individuals whose health literacy is low; strengthening the educational system and audiovisual messaging are critical approaches to improve health outcomes that might be applicable among the migrants.

Although community clean-ups have been conducted by Jawatankuasa Penduduk Perumahan (Housing Residential Committee), some apartments are rented out, posing a barrier to successful dengue prevention programme uptake by the new occupants as reported previously (34). Residents who retain water in containers owing to frequent water supply disruptions in these apartments should be encouraged to properly close the container or not leave standing water in containers for an extended length of time, as this can contribute to mosquito breeding sites. Furthermore, the Housing Residential Committee should be aware of vacant units in these apartments, which may result in the establishment of mosquito breeding sites (e.g. toilet bowels). On the other hand, inefficient garbage collection such as dustbin containers that are not functioning but left at the garbage area, infrequent garbage collection resulting in garbage remaining on the dustbin container for too long, dustbin containers with covers but left open after garbage collection resulting in the collection of water in solid waste and leading to an increase in dengue breeding sites (35). However, while enforcing monetary fines ("compounds") for failing to comply with breeding laws can help manage dengue, this technique may have certain downsides. The owners of these apartments, may be government officials in some cases, preventing them from being sanctioned as reported previously (36).

One of the factors thought to have a role in dengue transmission is dense populations (11). The presence of IgG seropositivity among various community residents in this study could be explained by the link between rich mosquito breeding areas (38) and high population density with high mobility. Not surprisingly, people who live in high-rise residential structures are more likely to be IgG seropositive than those who live in single or terraced houses, (11) who also experience more frequent fogging associated with mosquito reproduction. The current study, however, was unable to evaluate the link between seroprevalence and dengue because the sample size of residents with IgM seropositivity was insufficient.

The mean KAP scores were shown to be fairly correlated using the self-reported questionnaires employed in this study. In the study area, when residents' knowledge increased, their attitudes and/or practices improved as well, which is similar to other previous studies $(19,39)$. It is also possible that some people exhibit favourable behaviours initially, but subsequently lose interest when their efforts are not rewarded by their peers. Seeing results such as a drop in Aedes population or dengue cases may encourage them to keep doing what they're doing (40). The reluctance to have good preventive practices could also be related to the 'reactive approaches' they used or received, as they are only notified when dengue cases appear and then take appropriate action. Furthermore, despite different attempts and activities to provide information and guidance to the public, a lackadaisical attitude within the resident's community may have resulted in poor dengue preventive practises. Continuous motivation, such as telling residents when dengue-positive mosquitoes are identified and reinforcing their capacity to successfully carry out source reduction, has been reported to improve people's attitudes and actions (41). Recently, the Sabah state government implemented a community-centered strategy to empower and mobilise the community through the implementation of the Communication for Behavioral Impact (COMBI), in which volunteers selected from among the community would lead prevention activities such as 
gotong-royong and conduct inspections and eliminate mosquito breeding grounds inside and outside residential premises (42). It is relatively easy to modify knowledge and practice - but inherited and poor habits, on the other hand, are difficult to break with simple knowledge exchange, requiring multiple treatments, processes, and time. Health education programmes must take a more personal and practical approach to achieve this. Health officials should perform house-to-house inspections not just for Aedes surveillance but also to convey information and educate residents. One strategy to achieve this is to make changes to curriculums and provide continuing professional development to healthcare workers in order to promote cultural competency and, as a result, help to improve local and migrant attitudes around dengue fever (43). Although there was no association between attitude and practice in the current investigation, a Vietnamese study found that boosting attitude could improve dengue prevention practice at the same time (44). One explanation is that the population in the present study is mixed, with people from various sociocultural backgrounds.

There are certain limitations to this study that should be addressed. Firstly, because the majority of the participating residents in this study are pregnant women, the findings cannot be applied to the entire population of the hotspot area. The most important sample attribute that may or may not be representative of Sabah in this study is ethnicity. We acknowledge the fact that the study's ethnicity distribution is not representative of the multi-ethnic Sabah population, with each ethnic group having distinct cultures and beliefs that may impact their KAP.

\section{Conclusion}

This study revealed knowledge regarding dengue symptoms, transmission and vector control measures to be generally high among residents at a dengue hotspot: Taman Telipok Ria and Taman Sri Rugading, Telipok Sabah. A significant difference was also observed between local Sabahan and migrants in terms of their KAP. Despite indications of a link between knowledge and attitude or knowledge and practice, some knowledge about dengue and prevention does not lead to a positive attitude or practice. Conventional health education methods should be adjusted to stimulate social mobilisation among the admixed population. Bottom-up techniques combined with a multi-disciplinary approach should be used to influence people's attitudes and behaviours, particularly among migrants, about their role in combating dengue fever and eliminating vector breeding grounds. Clearly, a collaborate efforts of government sectors, private sectors, housing residential committee and community residents is required.

\section{Abbreviations}

EFA: exploratory factor analysis; EDTA: ethylenediaminetetraacetic acid; IgM: Immunoglobulin M; IgG: Immunoglobulin G

\section{Declarations}

\section{Ethics approval and consent to participate}

This research obtained ethical approval from the Sabah State Health Department [(53) dlm.JKN(SB)100-13] and Universiti Malaysia Sabah Research Ethics Committee [JKEtikaa 3/18 (3)] in accordance with the Declaration of Helsinki. In addition, permission to enter residences of residents was obtained from the district police office. A written informed consent was obtained from the residents prior to their participation in the study.

\section{Consent for publication}

The authors give consent for publication 


\section{Availability of data and materials}

All data generated or analysed during this study are included in this published article [and its supplementary information files].

\section{Competing interests}

The authors declare that they have no conflict of interest

\section{Funding}

The research was funded by the Universiti Malaysia Sabah: Skim Penyelidikan Pensyarah Lantikan Baru (SLB01812018) and Skim Penyelidikan Bidang Keutamaan (SBK0414-2018).

\section{Authors' contributions}

R.M.G, M.S.S, and Y.N.A. and N.A conceived and design the study including questionnaire designing and analysis and data collection, drafting manuscript. S.M.S, W.Y.L and Y.S.W provided critical comments. All authors read and approved the final manuscript

\section{Acknowledgements}

We are thankful to Assistant Medical Officers, Health Inspectors, and staff nurses for assisting in sample collection and patient recruitment. Also, appreciation goes to all community residents who have volunteered to participate in this study.

\section{References}

1. Ministry of Health Malaysia. History and Epidemiology of Dengue. http://denggi.myhealth.gov.my/history-andepidemiology-of-dengue/?lang=en (2021).

2. Ahmad R, Suzilah I, Wan Najdah WM, Topek O, Mustafakamal I, Lee HL. Factors determining dengue outbreak in Malaysia. PLoS One. 2018;13(2):e0193326. https://doi.org/10.1371/journal.pone.0193326

3. Tan W, Liew JW, Selvarajoo S, Lim XY, Foo CJ, Refai WF, et al. Inapparent dengue in a community living among dengue-positive Aedes mosquitoes and in a hospital in Klang Valley, Malaysia. Acta tropica 2020;204:105330. https://doi.org/10.1016/j.actatropica.2020.105330

4. Murphy A, Rajahram GS, Jilip J, Maluda M, William T, Hu W, et al. Incidence and epidemiological features of dengue in Sabah, Malaysia. PLoS neglected tropical diseases 2020;14(5):e0007504. https://doi.org/10.1371/journal.pntd.0007504

5. Department of Statistics Sabah. Sabah statistic yearbook. http://www.malaysiaeconomy.net/download/18072016_1.pdf. (2014)

6. Informasi Malaysia. Senarai Etnik di Sabah. https://infomasimalaysia.wordpress.com/2017/01/15/first-blogpost/ (2017).

7. National Population and Family Planning Development Board (NPFDB). Report on Indonesian workers in Tawau Sabah. Kuala Lumpur, Malaysia. https://mprh.Ippkn.gov.my/2019/05/06/laporan-kajian-pekerja-indonesia-dibahagian-tawau-sabah/ (2014).

8. Kurus B. Migrant labor: the Sabah experience. Asian and Pacific Migration Journal 1998; 7(2-3):281-95. https://doi.org/10.1177\%2F011719689800700208 
9. Azizah K. Filipino refugees in Sabah: State responses, public stereotypes and the dilemma over their future. Japanese Journal of Southeast Asian Studies 2009; 47(1):52-88. https://doi.org/10.20495/tak.47.1_52

10. Shabbir W, Pilz J, Naeem A. A spatial-temporal study for the spread of dengue depending on climate factors in Pakistan (2006-2017). BMC Public Health. 2020;20(1):1-0. https://doi.org/10.1186/s12889-020-08846-8

11. Guad RM, Wu YS, Aung YN, Sekaran SD, Wilke AB, Low WY, et al. Different Domains of Dengue Research in Malaysia: A Systematic Review and Meta-Analysis of Questionnaire-Based Studies. International Journal of Environmental Research and Public Health 2021;18(9):4474. https://doi.org/10.3390/ijerph18094474

12. Malaysia Ministry of Health. Hotspot Locality List. iDengue Portal. http://idengue.remotesensing.gov.my/idengue/page2.php?kandungan=hotspot.php (2017).

13. Constitution of Malaysia 1957 (Citizenship). http://www.commonlii.org/my/legis/const/1957/3.html.

14. Faul F, Erdfelder E, Lang AG, Buchner A. G* Power 3: A flexible statistical power analysis program for the social, behavioral, and biomedical sciences. Behavior research methods 2007; 39(2):175-91. https://doi.org/10.3758/BF03193146

15. Guad RM, Mangantig E, Low WY, Taylor-Robinson AW, Azzani M, Sekaran SD, Sim MS, et al. Development and validation of a structured survey questionnaire on knowledge, attitude, preventive practice, and treatment-seeking behaviour regarding dengue among the resident population of Sabah, Malaysia: an exploratory factor analysis. BMC infectious diseases 2021; 21(1):1-1. https://doi.org/10.1186/s12879-021-06606-6

16. Wang SM, Sekaran SD. Early diagnosis of Dengue infection using a commercial Dengue Duo rapid test kit for the detection of NS1, IGM, and IGG. The American journal of tropical medicine and hygiene 2010; 83(3):690. https://dx.doi.org/10.4269\%2Fajtmh.2010.10-0117

17. Yboa BC, Labrague LJ. Dengue knowledge and preventive practices among rural residents in Samar province, Philippines. American Journal of Public Health Research 2013; 1(2):47-52. https://doi:10.12691/ajphr-1-2-2

18. Selvarajoo S, Liew JW, Tan W, Lim XY, Refai WF, Zaki RA, et al. Knowledge, attitude and practice on dengue prevention and dengue seroprevalence in a dengue hotspot in Malaysia: A cross-sectional study. Scientific reports 2020;10(1):1-3. https://doi.org/10.1038/s41598-020-66212-5

19. Dhimal M, Aryal KK, Dhimal ML, Gautam I, Singh SP, Bhusal CL, et al. Knowledge, attitude and practice regarding dengue fever among the healthy population of highland and lowland communities in central Nepal. PloS one 2014; 9(7):e102028. https://doi.org/10.1371/journal.pone.0102028

20. Ghani NA, Shohaimi S, Hee AK, Chee HY, Emmanuel O, Alaba Ajibola LS. Comparison of knowledge, attitude, and practice among communities living in hotspot and non-hotspot areas of dengue in Selangor, Malaysia. Tropical medicine and infectious disease 2019;4(1):37. https://doi.org/10.3390/tropicalmed4010037

21. Lentillon-Kaestner V, Guillet-Descas E, Martinent G, Cece V. Validity and reliability of questionnaire on perceived professional identity among teachers (QIPPE) scores. Studies in Educational Evaluation 2018;59:235-43. https://doi.org/10.1016/j.stueduc.2018.09.003

22. Terwee CB, Bot SD, de Boer MR, van der Windt DA, Knol DL, Dekker J, et al. Quality criteria were proposed for measurement properties of health status questionnaires. Journal of clinical epidemiology 2007;60(1):34-42. https://doi.org/10.1016/j.jclinepi.2006.03.012

23. Pouliot SH, Xiong X, Harville E, Paz-Soldan V, Tomashek KM, Breart G, et al. Maternal dengue and pregnancy outcomes: a systematic review. Obstetrical \& gynecological survey 2010;65(2):107-18. https://doi: 10.1097/OGX.0b013e3181cb8fbc

24. Tan PC, Rajasingam G, Devi S, Omar SZ. Dengue infection in pregnancy: prevalence, vertical transmission, and pregnancy outcome. Obstetrics \& Gynecology 2008;111(5):1111-7.

http://journals.Iww.com/greenjournal/abstract/2008/05000/dengue_infection_in_pregnancy_prevalence,.15.aspx 
25. Kyu HH, Thu M, Van der Putten M. Myanmar migrant woman caretakers on prevention of dengue fever: A study on knowledge, attitude and practices in Tak Province, Thailand. Hospital 2005;27(9.9). https://citeseerx.ist.psu.edu/viewdoc/download?doi=10.1.1.616.2024\&rep=rep1\&type=pdf

26. van Wijk M, Naing S, Diaz Franchy S, Heslop RT, Novoa Lozano I, Vila J, et al. Perception and knowledge of the effect of climate change on infectious diseases within the general public: A multinational cross-sectional surveybased study. PloS one 2020;15(11):e0241579. https://doi.org/10.1371/journal.pone.0241579

27. Huda BZ, Ghebrehiwot L. Factors associated with knowledge and attitude on prevention of dengue fever among international postgraduate students in a Malaysian university. International Journal of Public Health and Clinical Sciences 2018;5(4):123-32.

28. University of Twente. Explaining Health Belief Model. https://www.utwente.nl/en/bms/communication-theories/ (2021).

29. Kamel MN, Gnanakkan BD, Fauzi FZ, Hanafi MI, Selvarajah G, Jabar SA, et al. The KAP study on dengue among community in Taman Salak Baiduri, Sepang, Selangor. Int. J. Sci. Healthc. Res 2017;18:2. http:/ ijshr.com/IJSHR_Vol.2_Issue.3_July2017/IJSHR005.pdf

30. Al-Dubai SA, Ganasegeran K, Mohanad Rahman A, Alshagga MA, Saif-Ali R. Factors affecting dengue fever knowledge, attitudes and practices among selected urban, semi-urban and rural communities in Malaysia. Southeast Asian J Trop Med Public Health 2013;44(1):37-49.

31. Diaz-Quijano FA, Martínez-Vega RA, Rodriguez-Morales AJ, Rojas-Calero RA, Luna-González ML, Díaz-Quijano RG. Association between the level of education and knowledge, attitudes and practices regarding dengue in the Caribbean region of Colombia. BMC Public Health 2018;18(1):1-0. https://doi.org/10.1186/s12889-018-5055-z

32. Berkman ND, Sheridan SL, Donahue KE, Halpern DJ, Crotty K. Low health literacy and health outcomes: an updated systematic review. Annals of internal medicine 2011;155(2):97-107. https://doi.org/10.7326/0003-4819155-2-201107190-00005

33. Gilder ME, Moo P, Hashmi A, Praisaengdet N, Wai K, Pimanpanarak M, et al. "I can't read and don't understand": Health literacy and health messaging about folic acid for neural tube defect prevention in a migrant population on the Myanmar-Thailand border. PloS one 2019;14(6):e0218138. https://doi.org/10.1371/journal.pone.0218138

34. Udayanga L, Gunathilaka N, Iqbal MC, Pahalagedara K, Amarasinghe US, Abeyewickreme W. Socio-economic, Knowledge Attitude Practices (KAP), household related and demographic based appearance of non-dengue infected individuals in high dengue risk areas of Kandy District, Sri Lanka. BMC infectious diseases 2018;18(1):14. https://doi.org/10.1186/s12879-018-2995-y

35. Abeyewickreme W, Wickremasinghe AR, Karunatilake K, Sommerfeld J, Axel K. Community mobilization and household level waste management for dengue vector control in Gampaha district of Sri Lanka; an intervention study. Pathogens and global health 2012;106(8):479-87. https://doi.org/10.1179/2047773212Y.0000000060

36. Mulligan K, Elliott SJ, Schuster-Wallace C. The place of health and the health of place: Dengue fever and urban governance in Putrajaya, Malaysia. Health \& place 2012;18(3):613-20.

https://doi.org/10.1016/j.healthplace.2012.01.001

37. Chen CD, Nazni WA, Lee HL, Seleena B, Mohd Masri S, Chiang YF, et al. Mixed breeding of Aedes aegypti (L.) and Aedes albopictus Skuse in four dengue endemic areas in Kuala Lumpur and Selangor, Malaysia. Tropical biomedicine 2006;23(2):224-7.

38. Mayxay M, Cui W, Thammavong S, Khensakhou K, Vongxay V, Inthasoum L, Sychareun V, Armstrong G. Dengue in peri-urban Pak-Ngum district, Vientiane capital of Laos: a community survey on knowledge, attitudes and practices. BMC public health. 2013;13(1):1-8. https://doi.org/10.1186/1471-2458-13-434

Page $12 / 20$ 
39. Sulistyawati S, Dwi Astuti F, Rahmah Umniyati S, Tunggul Satoto TB, Lazuardi L, Nilsson M, et al. Dengue vector control through community empowerment: lessons learned from a community-based study in Yogyakarta, Indonesia. International journal of environmental research and public health 2019;16(6):1013.

https://doi.org/10.3390/ijerph16061013

40. Liew JW, Selvarajoo S, Tan W, Zaki RA, Vythilingam I. Gravid oviposition sticky trap and dengue non-structural 1 antigen test for early surveillance of dengue in multi-storey dwellings: study protocol of a cluster randomized controlled trial. Infectious diseases of poverty 2019;8(1):1-2. https:// doi.org/10.1186/s40249-019-0584-y

41. Borneo Post Online. Mobile clinic service launched. https://www.theborneopost.com/2017/05/22/mobile-clinicservice-launched/

42. Schwarzer R, Hamilton K. Changing behavior using the health action process approach. The handbook of behavior change 2020:89-103.

43. IOM Human Migration. How the World Views Migration. https://publications.iom.int/books/how-world-viewsmigration. (2021).

\section{Tables}

Table 1: Sociodemographic characteristics of the residents. 


\begin{tabular}{|c|c|}
\hline Characteristics & $\mathrm{n}, \%$ \\
\hline Age (mean \pm SD) (years) & $31.24 \pm 9.467$ \\
\hline \multicolumn{2}{|l|}{ Gender } \\
\hline Male & $55(11.9)$ \\
\hline Female & $408(88.1)$ \\
\hline \multicolumn{2}{|l|}{ Pregnancy } \\
\hline Positive & $399(86.2)$ \\
\hline Negative & $64(13.8)$ \\
\hline \multicolumn{2}{|l|}{ Nationality } \\
\hline Malaysian & $137(29.6)$ \\
\hline Non-Malaysian & $326(70.4)$ \\
\hline \multicolumn{2}{|l|}{ Ethnicity } \\
\hline Kadazan-dusun & $57(12.3)$ \\
\hline Bajau & $174(37.6)$ \\
\hline Bugis & $71(15.3)$ \\
\hline Suluk & $64(13.8)$ \\
\hline Others & $97(20.9)$ \\
\hline \multicolumn{2}{|l|}{ Educational attainment } \\
\hline No school/ Primary school & $120(25.9)$ \\
\hline Secondary school/ College/university & $343(74.1)$ \\
\hline \multicolumn{2}{|l|}{ Occupation } \\
\hline Working & $130(28.1)$ \\
\hline Non-working & $333(71.9)$ \\
\hline \multicolumn{2}{|l|}{ Monthly income } \\
\hline$<=$ MYR 1,000 & $142(30.7)$ \\
\hline >MYR 1,000 & $321(69.3)$ \\
\hline \multicolumn{2}{|l|}{ History of dengue } \\
\hline Yes & $33(7.1)$ \\
\hline No & $430(92.9)$ \\
\hline \multicolumn{2}{|l|}{ Dengue seroprevalence $(n=200)$} \\
\hline IgM positive & $5(7.1)$ \\
\hline IgG positive & $63(74.1)$ \\
\hline \multicolumn{2}{|l|}{ Type of house } \\
\hline Flat & $445(96.1)$ \\
\hline
\end{tabular}


Note: (1.00 USD is equivalent to MYR=Malaysian Ringgit 4.12); IgM=Immunoglobulin $M$; IgG=Immunoglobulin G.

Table 2: Knowledge of dengue among residents. 


\begin{tabular}{|c|c|c|c|c|}
\hline \multirow[t]{2}{*}{ Statement } & \multicolumn{4}{|c|}{ Responses } \\
\hline & $\begin{array}{l}\text { Yes }(n, \\
\%)\end{array}$ & $\begin{array}{l}\text { No }(n, \\
\%)\end{array}$ & $\begin{array}{l}\text { Don't know } \\
(n, \%)\end{array}$ & $\begin{array}{l}\text { Total } \\
(\mathrm{N})\end{array}$ \\
\hline \multicolumn{5}{|l|}{ Sign of dengue } \\
\hline - Fever* & $\begin{array}{l}390 \\
(84.4)\end{array}$ & $\begin{array}{l}26 \\
(5.6)\end{array}$ & $46(10.0)$ & 462 \\
\hline - Chills* & $\begin{array}{l}323 \\
(70.7)\end{array}$ & $\begin{array}{l}43 \\
(9.4)\end{array}$ & $91(19.9)$ & 457 \\
\hline - Nausea and vomiting* & $\begin{array}{l}255 \\
(56.0)\end{array}$ & $\begin{array}{l}70 \\
(15.4)\end{array}$ & $130(28.6)$ & 455 \\
\hline - Coughing & $\begin{array}{l}86 \\
(19.3)\end{array}$ & $\begin{array}{l}195 \\
(43.1)\end{array}$ & $171(37.8)$ & 452 \\
\hline - Enlarged lymph nodes & $\begin{array}{l}63 \\
(13.9)\end{array}$ & $\begin{array}{l}155 \\
(34.2)\end{array}$ & $235(51.9)$ & 453 \\
\hline Dengue a contagious disease* & $\begin{array}{l}141 \\
(30.5)\end{array}$ & $\begin{array}{l}236 \\
(51.1)\end{array}$ & $85(18.4)$ & 462 \\
\hline Mosquitoes is the carrier of dengue* & $\begin{array}{l}433 \\
(94.7)\end{array}$ & $3(0.7)$ & $21(4.6)$ & 457 \\
\hline \multicolumn{5}{|l|}{ Types of mosquito carries dengue } \\
\hline - Culex & $8(1.7)$ & $\begin{array}{l}81 \\
(17.7)\end{array}$ & $369(80.6)$ & 458 \\
\hline - Aedes* & $\begin{array}{l}370 \\
(79.9)\end{array}$ & $4(0.9)$ & $89(19.2)$ & 463 \\
\hline - Anopheles & $\begin{array}{l}10 \\
(2.2)\end{array}$ & $\begin{array}{l}70 \\
(15.3)\end{array}$ & $378(82.5)$ & 458 \\
\hline - Mansonii & $2(0.4)$ & $\begin{array}{l}73 \\
(15.8)\end{array}$ & $383(82.7)$ & 463 \\
\hline \multicolumn{5}{|c|}{$\begin{array}{l}\text { Time of day dengue carriers more likely to cause infection in } \\
\text { humans }\end{array}$} \\
\hline & $\begin{array}{l}285 \\
(62.5)\end{array}$ & $\begin{array}{l}35 \\
(7.7)\end{array}$ & $136(29.8)$ & 456 \\
\hline - Morning and noon & $\begin{array}{l}60 \\
(13.3)\end{array}$ & $\begin{array}{l}148 \\
(32.7)\end{array}$ & $244(54.0)$ & 452 \\
\hline - Evening and midnight & $\begin{array}{l}171 \\
(37.7)\end{array}$ & $\begin{array}{l}82 \\
(18.0)\end{array}$ & $201(44.3)$ & 454 \\
\hline - All the time & $\begin{array}{l}148 \\
(32.5)\end{array}$ & $\begin{array}{l}105 \\
(23.0)\end{array}$ & $203(44.5)$ & 456 \\
\hline \multicolumn{5}{|l|}{ Breeding place for dengue fever carriers } \\
\hline - Discarded food container* & $\begin{array}{l}285 \\
(64.0)\end{array}$ & $\begin{array}{l}79 \\
(17.8)\end{array}$ & $81(18.2)$ & 445 \\
\hline - Open pool of water* & $\begin{array}{l}434 \\
(94.8)\end{array}$ & $8(1.7)$ & $16(3.5)$ & 458 \\
\hline - Uncovered water reservoir* & $\begin{array}{l}311 \\
(69.9)\end{array}$ & $\begin{array}{l}60 \\
(13.5)\end{array}$ & $74(16.6)$ & 445 \\
\hline
\end{tabular}




\begin{tabular}{|c|c|c|c|c|}
\hline - Flowing water & $\begin{array}{l}79 \\
(18.0)\end{array}$ & $\begin{array}{l}244 \\
(55.6)\end{array}$ & $116(26.4)$ & 439 \\
\hline Presence of a specific treatment for dengue & $\begin{array}{l}274 \\
(60.8)\end{array}$ & $\begin{array}{l}65 \\
(14.4)\end{array}$ & $112(24.8)$ & 457 \\
\hline \multicolumn{5}{|l|}{ Treatment options for dengue } \\
\hline - Plenty of rest* & $\begin{array}{l}258 \\
(57.6)\end{array}$ & $\begin{array}{l}56 \\
(12.5)\end{array}$ & $134(29.9)$ & 448 \\
\hline - Drinking water abundantly* & $\begin{array}{l}347 \\
(76.3)\end{array}$ & $\begin{array}{l}22 \\
(4.8)\end{array}$ & $86(18.9)$ & 445 \\
\hline - Taking Panadol & $\begin{array}{l}161 \\
(36.3)\end{array}$ & $\begin{array}{l}97 \\
(21.8)\end{array}$ & $186(41.9)$ & 444 \\
\hline - Traditional herbal remedies & $\begin{array}{l}76 \\
(17.9)\end{array}$ & $\begin{array}{l}125 \\
(28.5)\end{array}$ & $237(54.1)$ & 438 \\
\hline $\begin{array}{l}\text { Awareness on the existence of fines if mosquito larvae are found in } \\
\text { residential property }\end{array}$ & $\begin{array}{l}377 \\
(87.5)\end{array}$ & $\begin{array}{l}15 \\
(3.5)\end{array}$ & $39(9.0)$ & 431 \\
\hline
\end{tabular}

Note: * correct answer

Table 3: Attitude of the residents towards dengue prevention.

\begin{tabular}{|c|c|c|c|c|c|c|}
\hline Statement & $\begin{array}{l}\text { Strongly } \\
\text { agree } \\
\text { n (\%) }\end{array}$ & $\begin{array}{l}\text { Agree } \\
\text { n (\%) }\end{array}$ & $\begin{array}{l}\text { Not } \\
\text { sure } \\
\mathrm{n}(\%)\end{array}$ & $\begin{array}{l}\text { Don't } \\
\text { agree } \\
\mathrm{n}(\%)\end{array}$ & $\begin{array}{l}\text { Strongly } \\
\text { don't } \\
\text { agree } \\
\text { n (\%) }\end{array}$ & $\begin{array}{l}\text { Total } \\
(\mathrm{N})\end{array}$ \\
\hline Dengue is a type of disease that cannot be prevented & $34(7.7)$ & $\begin{array}{l}70 \\
(15.8)\end{array}$ & $\begin{array}{l}88 \\
(19.9)\end{array}$ & $\begin{array}{l}200 \\
(45.2)\end{array}$ & $\begin{array}{l}50 \\
(11.3)\end{array}$ & 442 \\
\hline $\begin{array}{l}\text { Disposal of mosquito larvae is a waste of time and } \\
\text { troublesome }\end{array}$ & $11(2.5)$ & $\begin{array}{l}20 \\
(4.5)\end{array}$ & $\begin{array}{l}67 \\
(15.2)\end{array}$ & $\begin{array}{l}228 \\
(51.6)\end{array}$ & $\begin{array}{l}116 \\
(26.2)\end{array}$ & 442 \\
\hline $\begin{array}{l}\text { Killing mosquitoes carrying dengue is the only way to } \\
\text { control or prevent infection }\end{array}$ & $\begin{array}{l}76 \\
(17.2)\end{array}$ & $\begin{array}{l}123 \\
(27.8)\end{array}$ & $\begin{array}{l}95 \\
(21.5)\end{array}$ & $\begin{array}{l}95 \\
(21.5)\end{array}$ & $\begin{array}{l}53 \\
(12.0)\end{array}$ & 442 \\
\hline $\begin{array}{l}\text { Eradicating mosquito breeding grounds is the } \\
\text { responsibility of health professionals and volunteers } \\
\text { only }\end{array}$ & $\begin{array}{l}53 \\
(11.9)\end{array}$ & $\begin{array}{l}57 \\
(12.8)\end{array}$ & $\begin{array}{l}50 \\
(11.3)\end{array}$ & $\begin{array}{l}223 \\
(50.1)\end{array}$ & $\begin{array}{l}62 \\
(13.9)\end{array}$ & 445 \\
\hline $\begin{array}{l}\text { Supervised control and monitoring of suspected } \\
\text { mosquito breeding grounds should be undertaken at } \\
\text { least once a year }\end{array}$ & $\begin{array}{l}46 \\
(10.4)\end{array}$ & $\begin{array}{l}97 \\
(21.8)\end{array}$ & $\begin{array}{l}99 \\
(22.3)\end{array}$ & $\begin{array}{l}165 \\
(37.2)\end{array}$ & $37(8.3)$ & 442 \\
\hline 'Fogging' can prevent mosquito breeding completely & $\begin{array}{l}83 \\
(18.7)\end{array}$ & $\begin{array}{l}151 \\
(34.0)\end{array}$ & $\begin{array}{l}114 \\
(25.7)\end{array}$ & $\begin{array}{l}86 \\
(19.4)\end{array}$ & $10(2.2)$ & 444 \\
\hline Fines can help towards control of dengue & $\begin{array}{l}70 \\
(16.0)\end{array}$ & $\begin{array}{l}182 \\
(41.6)\end{array}$ & $\begin{array}{l}118 \\
(26.9)\end{array}$ & $\begin{array}{l}53 \\
(12.1)\end{array}$ & $15(3.4)$ & 438 \\
\hline $\begin{array}{l}\text { Health professionals are not required to inspect } \\
\text { residential properties }\end{array}$ & $10(2.3)$ & $\begin{array}{l}29 \\
(6.5)\end{array}$ & $\begin{array}{l}72 \\
(16.2)\end{array}$ & $\begin{array}{l}254 \\
(57.2)\end{array}$ & $\begin{array}{l}79 \\
(17.8)\end{array}$ & 444 \\
\hline
\end{tabular}


Table 4: Practices of the residents on dengue prevention.

\begin{tabular}{|c|c|c|c|c|}
\hline Statement & $\begin{array}{l}\text { Yes } \\
(n, \%)\end{array}$ & $\begin{array}{l}\text { No }(n, \\
\%)\end{array}$ & $\begin{array}{l}\text { Not } \\
\text { applicable } \\
(n, \%)\end{array}$ & $\begin{array}{l}\text { Total } \\
(\mathbf{N})\end{array}$ \\
\hline Are containers of water/wells in your residence covered? & $\begin{array}{l}309 \\
(69.9)\end{array}$ & $\begin{array}{l}11 \\
(2.5)\end{array}$ & $122(27.6)$ & 442 \\
\hline Do you close water containers/wells once you have finished using them? & $\begin{array}{l}315 \\
(71.4)\end{array}$ & $\begin{array}{l}4 \\
(0.9)\end{array}$ & $122(27.4)$ & 441 \\
\hline $\begin{array}{l}\text { Do you always check the condition of stored water in containers/wells if } \\
\text { you do not use them for more than five days? }\end{array}$ & $\begin{array}{l}296 \\
(67.0)\end{array}$ & $\begin{array}{l}23 \\
(5.2)\end{array}$ & $123(27.8)$ & 442 \\
\hline Do you put an abate $®$ in the reservoir in your residence? & $\begin{array}{l}127 \\
(28.7)\end{array}$ & $\begin{array}{l}194 \\
(43.9)\end{array}$ & $121(27.4)$ & 442 \\
\hline Have you ever checked for mosquito larvae in a discarded flower vase? & $\begin{array}{l}187 \\
(42.4)\end{array}$ & $\begin{array}{l}35 \\
(7.9)\end{array}$ & $219(49.7)$ & 441 \\
\hline If there is stagnant water in a flower vase, would you throw it away? & $\begin{array}{l}220 \\
(49.9)\end{array}$ & $\begin{array}{l}6 \\
(1.4)\end{array}$ & $215(48.7)$ & 441 \\
\hline $\begin{array}{l}\text { Have you ever checked your residence and property for a container/place } \\
\text { that could provide a mosquito breeding site? }\end{array}$ & $\begin{array}{l}358 \\
(81.7)\end{array}$ & $\begin{array}{l}75 \\
(17.1)\end{array}$ & $5(1.2)$ & 438 \\
\hline $\begin{array}{l}\text { Do you remove containers that can collect water and allow it to } \\
\text { stagnate? }\end{array}$ & $\begin{array}{l}411 \\
(93.8)\end{array}$ & $\begin{array}{l}24 \\
(5.5)\end{array}$ & $3(0.7)$ & 438 \\
\hline Do you check and clean the gutters of your residence each rainy season? & $\begin{array}{l}9 \\
(2.0)\end{array}$ & $\begin{array}{l}3 \\
(0.7)\end{array}$ & $426(97.3)$ & 438 \\
\hline $\begin{array}{l}\text { Do you consider eradicating Aedes mosquitoes is a shared } \\
\text { responsibility? }\end{array}$ & $\begin{array}{l}427 \\
(97.5)\end{array}$ & $\begin{array}{l}9 \\
(2.0)\end{array}$ & $2(0.5)$ & 438 \\
\hline $\begin{array}{l}\text { Would you allow the authorities to conduct dengue prevention activities } \\
\text { at your residence? }\end{array}$ & $\begin{array}{l}427 \\
(97.7)\end{array}$ & $\begin{array}{l}9 \\
(2.1)\end{array}$ & $1(0.2)$ & 437 \\
\hline
\end{tabular}

Table 5: Univariate predictors of good KAP. 


\begin{tabular}{|c|c|c|c|c|c|c|c|}
\hline \multirow[t]{2}{*}{ Characteristics } & & \multicolumn{2}{|c|}{ Knowledge } & \multicolumn{2}{|l|}{ Attitude } & \multicolumn{2}{|l|}{ Practice } \\
\hline & & cOR & $p$ & cOR & $p$ & cOR & $p$ \\
\hline \multirow[t]{2}{*}{ Age (years) } & $<=35$ year & 1.000 & \multirow[t]{2}{*}{0.8240} & 1.000 & \multirow[t]{2}{*}{0.9470} & 1.000 & \multirow[t]{2}{*}{0.2100} \\
\hline & $>35$ year & $\begin{array}{l}0.837 \\
(0.171- \\
4.096)\end{array}$ & & $\begin{array}{l}0.970(0.401- \\
2.350)\end{array}$ & & $\begin{array}{l}0.741(0.462- \\
1.190)\end{array}$ & \\
\hline \multirow[t]{2}{*}{ Gender } & Male & 1.000 & \multirow[t]{2}{*}{0.8155} & 1.000 & \multirow[t]{2}{*}{0.1930} & 1.000 & \multirow[t]{2}{*}{0.0054 * } \\
\hline & Female & $\begin{array}{l}1.274 \\
(0.156- \\
10.392)\end{array}$ & & $\begin{array}{l}0.513(0.198- \\
1.329)\end{array}$ & & $\begin{array}{l}2.651(1.257- \\
5.590)\end{array}$ & \\
\hline \multirow[t]{2}{*}{ Nationality } & Non-local & 1.000 & \multirow[t]{2}{*}{$0.0026 *$} & 1.000 & \multirow[t]{2}{*}{$0.0024^{*}$} & 1.000 & \multirow[t]{2}{*}{0.0593} \\
\hline & Local & $\begin{array}{l}8.673 \\
(1.774- \\
42.383)\end{array}$ & & $\begin{array}{l}3.333(1.529- \\
7.267)\end{array}$ & & $\begin{array}{l}1.511(0.986- \\
2.314)\end{array}$ & \\
\hline \multirow[t]{2}{*}{ Marital status } & Not married & 1.000 & \multirow[t]{2}{*}{0.7814} & 1.000 & \multirow[t]{2}{*}{0.2211} & 1.000 & \multirow[t]{2}{*}{0.2211} \\
\hline & Married & $\begin{array}{l}0.733 \\
(0.089- \\
6.043)\end{array}$ & & $\begin{array}{l}0.470(0.153- \\
1.447)\end{array}$ & & $\begin{array}{l}0.221(0.560- \\
2.765)\end{array}$ & \\
\hline \multirow[t]{2}{*}{$\begin{array}{l}\text { Level of } \\
\text { education }\end{array}$} & $\begin{array}{l}\text { No school/ } \\
\text { Primary }\end{array}$ & & & 1.000 & \multirow[t]{2}{*}{$0.009 *$} & 1.000 & \multirow[t]{2}{*}{$0.0461 *$} \\
\hline & $\begin{array}{l}\text { Secondary } \\
\text { and above }\end{array}$ & & & $\begin{array}{l}2.379(0.880- \\
10.062)\end{array}$ & & $\begin{array}{l}2.976(1.391- \\
4.071)\end{array}$ & \\
\hline \multirow[t]{2}{*}{ Employment } & Not working & 1.000 & \multirow[t]{2}{*}{0.8450} & 1.000 & \multirow[t]{2}{*}{0.1010} & 1.000 & \multirow[t]{2}{*}{0.4310} \\
\hline & Working & $\begin{array}{l}1.151 \\
(0.283- \\
4.680)\end{array}$ & & $\begin{array}{l}1.946(0.892- \\
4.244)\end{array}$ & & $\begin{array}{l}0.836(0.535- \\
1.308)\end{array}$ & \\
\hline \multirow{2}{*}{$\begin{array}{l}\text { Monthly } \\
\text { income }\end{array}$} & $<$ MYR 1,000 & 1.000 & \multirow[t]{2}{*}{0.5380} & 1.000 & \multirow[t]{2}{*}{0.2250} & 1.000 & \multirow[t]{2}{*}{0.9232} \\
\hline & MYR > 1,000 & $\begin{array}{l}1.613 \\
(0.330- \\
7.878)\end{array}$ & & $\begin{array}{l}1.732(0.330- \\
7.879)\end{array}$ & & $\begin{array}{l}0.473(0.661- \\
1.579)\end{array}$ & \\
\hline \multirow{2}{*}{$\begin{array}{l}\text { History of } \\
\text { dengue } \\
\text { infection }\end{array}$} & No & 1.000 & \multirow[t]{2}{*}{0.1472} & 1.000 & \multirow[t]{2}{*}{0.9800} & 1.000 & \multirow[t]{2}{*}{0.8063} \\
\hline & Yes & $\begin{array}{l}3.87 \\
(0.767- \\
19.558)\end{array}$ & & $\begin{array}{l}1.0193(0.230- \\
4.516)\end{array}$ & & $\begin{array}{l}1.105(0.500- \\
2.443)\end{array}$ & \\
\hline
\end{tabular}

Note: cOR, Crude odds ratio (at $95 \%$ confidence interval). *Significant P value $(p<0.05)$.

Table 6: Correlation between knowledge, attitude and practice. 


\begin{tabular}{|ll|}
\hline Characteristics & spearman rho $\left(r_{s}\right), \boldsymbol{p}$ \\
\hline Knowledge-attitude & $\mathbf{0 . 2 7 6 8 ( < 0 . 0 0 0 1 )}$ \\
\hline Attitude-practice & $-0.0039(0.9374)$ \\
\hline Knowledge-practice & $\mathbf{0 . 1 6 1 4}(\mathbf{0 . 0 0 1 4})$ \\
\hline
\end{tabular}

\section{Figures}

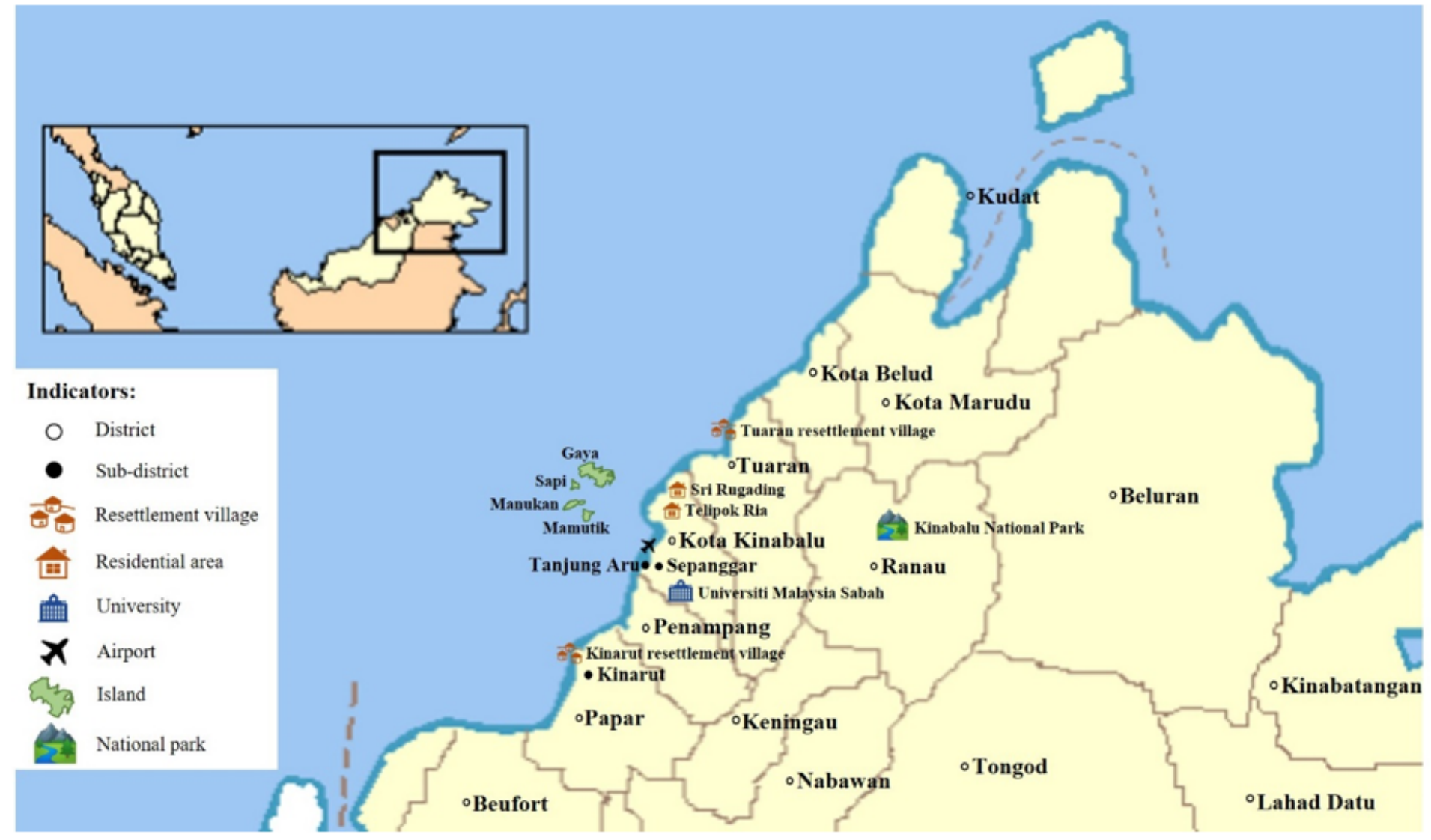

Figure 1

Location of Telipok resettlement village, Kinarut resettlement village, Taman Telipok Ria and Taman Sri Rugading

\section{Supplementary Files}

This is a list of supplementary files associated with this preprint. Click to download.

- SupplementaryMaterialquestionnaire.docx 